\title{
THE NEED FOR DEFENCE IN THE ALICANTE COAST IN THE 16TH CENTURY: THE REJAS TOWER
}

\author{
Ma ASUNCIÓN LÓPEZ-PERAL, ENCARNACIÓN GARCÍA-GONZÁLEZ \& Ma DOLORES \\ ANDÚJAR-MONTOYA \\ University of Alicante, Spain.
}

\begin{abstract}
The military architecture is one of the most interesting constructive aspects of the 16th century in Alicante. During this period, the Berber pirates devastated the Mediterranean coasts. The defence of the territory was organized from the construction of watchtowers. The watchtowers mission was to alert the nearest workhouses to the continuous sieges. These towers were built next to the sea and had a military nature. In Alicante, in the rural area named as La Condomina, several fortified houses appeared scattered among the rural paths with their square or rectangular towers. They are known as Torres de la Huerta, and they had civil nature because these constructions were built next to hamlets and surrounded by walls that protected them. The enemy could be seen from the watchtowers on the coast; meanwhile those towers placed in the interior were used as refuge to the local inhabitants. A greater number of these last towers were built during the reign of Felipe II. This article focuses on the constructive aspects and original materials used in Rejas Tower, one of the most outstanding and best preserved towers in this territory. This building is an important exponent in the defensive architecture in Alicante during this period due to the construction techniques and original materials used.

Keywords: defence buildings, fortified houses, military architecture, watchtowers.
\end{abstract}

\section{INTRODUCTION - MILITARY ARCHITECTURE IN THE 16TH CENTURY: THE WATCHTOWERS}

Alicante history has a difficult period, which dates back to the 16th and 17th centuries, when, as in the rest of the Mediterranean coast, the Berber pirates were intruded on its shores. This period coincides with the reign of two of the greatest pirates of all time: Barbarroja and Dragut [1]. It was necessary to organize a good defensive system based on watchtowers, whose purpose was to alert the nearby farmhouses, from the continuous sieges.

Watchtowers were built on the coast, in the capes, in the incoming and outgoing land at the sea, as guardians of our territory. They appear near El Pilar de la Horadada and Torrevieja by the south and are sited very close to Denia by the north. These towers were strategically placed and from there the enemy could be seen before he reached the coast. These towers were built without outside showiness; they have done their part due to the excellent strength of their walls and difficult access [2,3].

\section{THE NEED FOR REFUGE: THE TOWERS PLACED IN LA CONDOMINA}

Alicante and nearby towns suffered looting and devastation during the reign of these pirates. It was in the days of Carlos I and his son Felipe II when the towers of La Condomina were built to safeguard the peasants from the incursions of the Berber and Turks [4].

Santa Barbara castle gave shelter to the inhabitants of the city and nearby towns, but the pirate ships arrived to their coasts as fast as they could so there was no time for the peasants to take shelter in the castle [5]. For that reason, the Condomina towers were built years later. In this sense, the difference between the towers raised by the sea and the interior towers must be emphasized. The first ones were military in nature, while the second ones were civil in nature, because they were located next to hamlets and surrounded by walls that protected them. 
The Rejas Tower belongs to this last group. The tower is attached to the house and surrounded by vast gardens. It is currently in a perfect state of preservation [6].

\section{GEOGRAPHIC LOCATION}

The largest number of this kind of towers are located in the area known as La Condomina, a territory nestled within an irregular polygon, whose edges are Vistahermosa de la Cruz, Santa Faz, San Juan country, San Juan beach and La Albufereta. Near San Juan and Muchamiel, far from the sea, the towers decrease in number and density [7].

Several fortified houses with their square or rectangular towers are seen in this area, scattered among the roads. Their location was originally constrained by the irrigation ditches. This zone of Alicante was irrigated only by the flow of River Montnegre. Montnegre's waters enjoyment belonged to the inhabitants of Alicante even though the river started outside the general terms of the city. It was a donation to Alicante residents according to different Royal Privileges during the 13th century. (The irrigation privilege of these lands dates from 1252, when King Alfonso X granted these lands to the people of Alicante and neighbouring villages.) [8].

\section{CONSTRUCTIVE FEATURES OF THE TOWER}

The construction of the tower is previous to that of the house. The plants of the towers are square or slightly rectangular in shape. The bottom of the tower is different from the rest. It can be in the form of pyramidal plinth, or with parallel faces, but are thicker than the rest of the tower. In few occasions the whole tower seems to take the shape of a pyramidal trunk (Fig. 1).

Two elements are characteristics of all of them: the robustness of their walls and the high access. The thickness of the walls is around a metre and is made of ashlars or masonry. As reminiscent of their defensive origin, they keep the access door at the first floor of the house to which they are attached. In all cases, it is a small dimension entrance, of rough wood, framed with well-carved ashlars. The towers coronation is a stone cornice with a battlement or several different forms of pinnacles $[9,10]$ (Fig. 2).
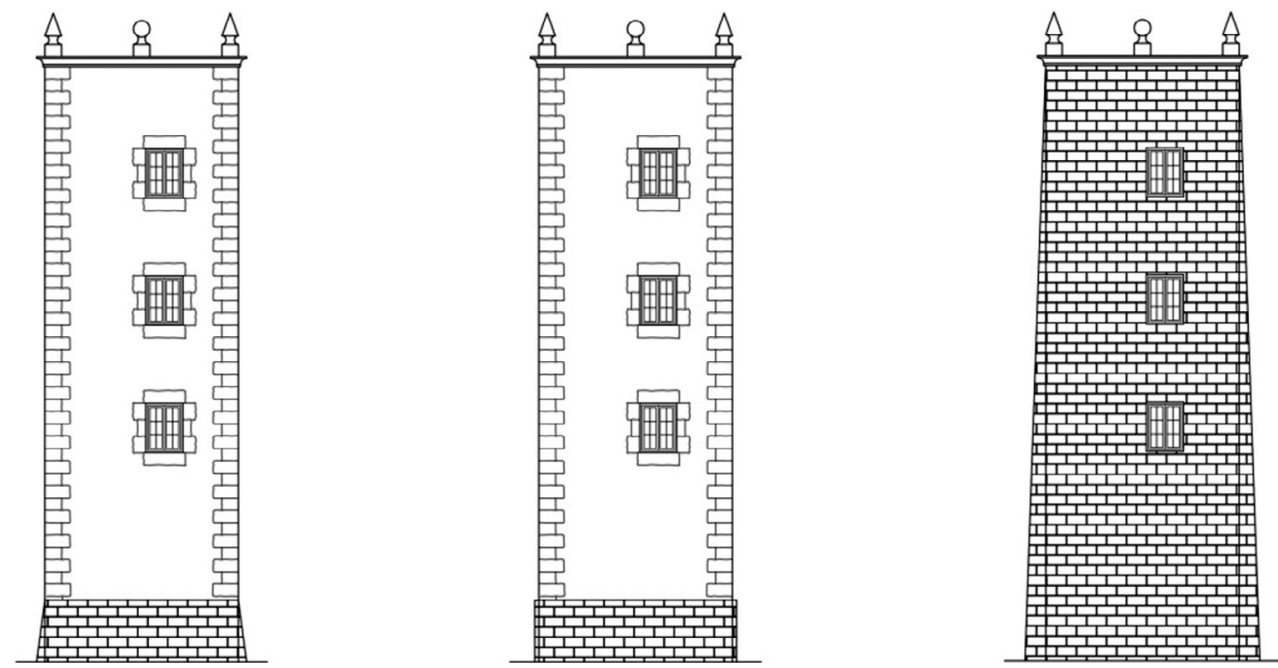

Figure 1: Towers with different bottom types. 


\section{Defensive towers}

Tower considerably higher and wide with minimum conditions of habitability and maximum for the defence, of reduced surface and usually of high single access

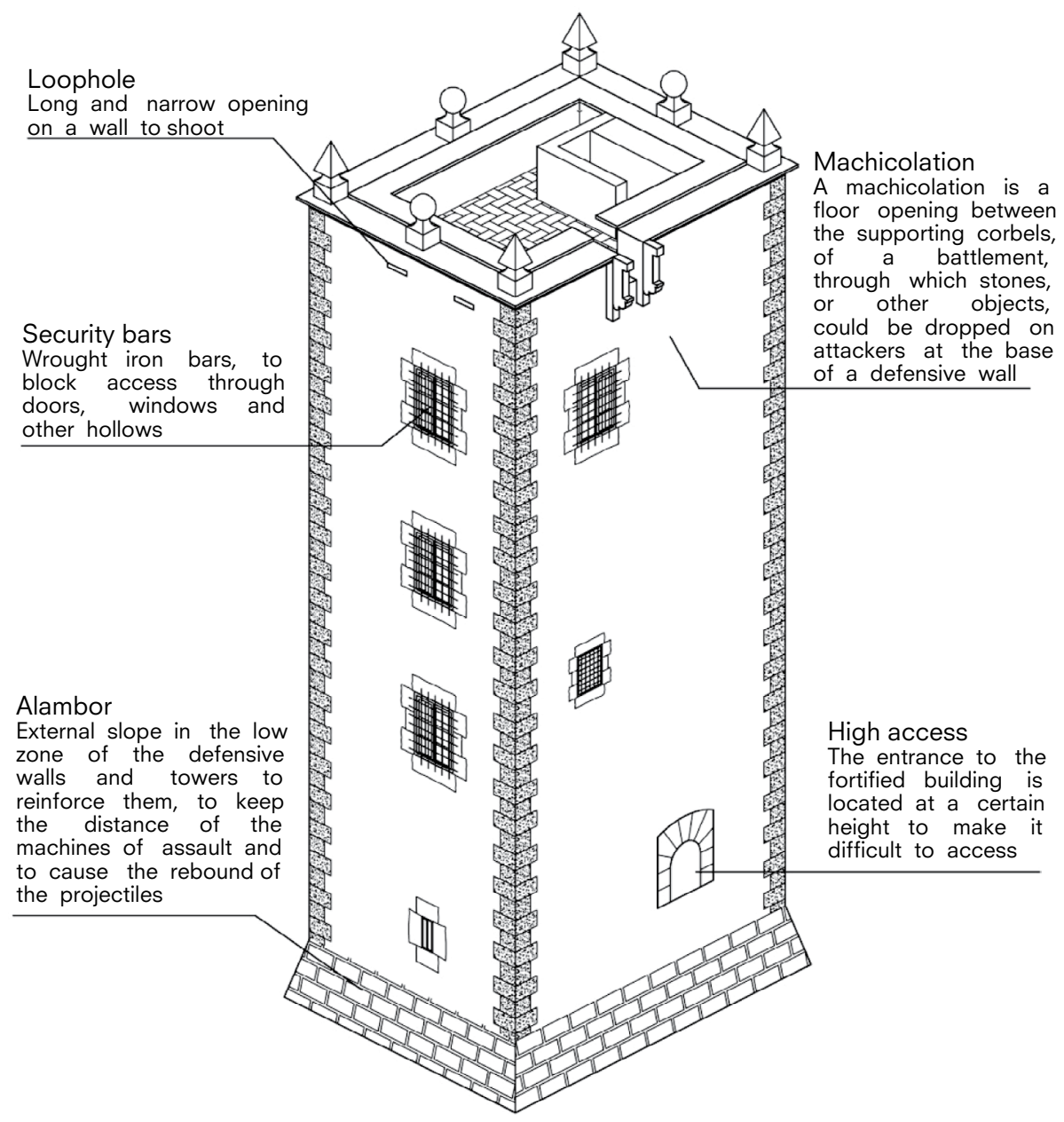

Figure 2: The defensive tower elements.

\subsection{Rejas Tower - Description}

Rejas Tower is located in the Condomina area, at the west side of the old road from Alicante to Benimagrell. It is integrated into the house with ground floor and first floor. The exact origin of the tower stone is unknown. The land in this area near the beach does not have a high-quality resistant. The start tower has a pyramidal plinth shape with a height of one metre approximately. The tower has a prismatic form, with walls raised vertically. It is $6.20 \times 4.70$ metres and the thickness of its walls is of about 85 centimetres. It is built in huge ashlars stones with reinforcements in the corners and the openings surrounded. The stones are joined with lime mortar. It has a yellowish coloration, typical of the sandstone of the area. The tower consists of ground floor, four floors and cover floor (Fig. 3). 

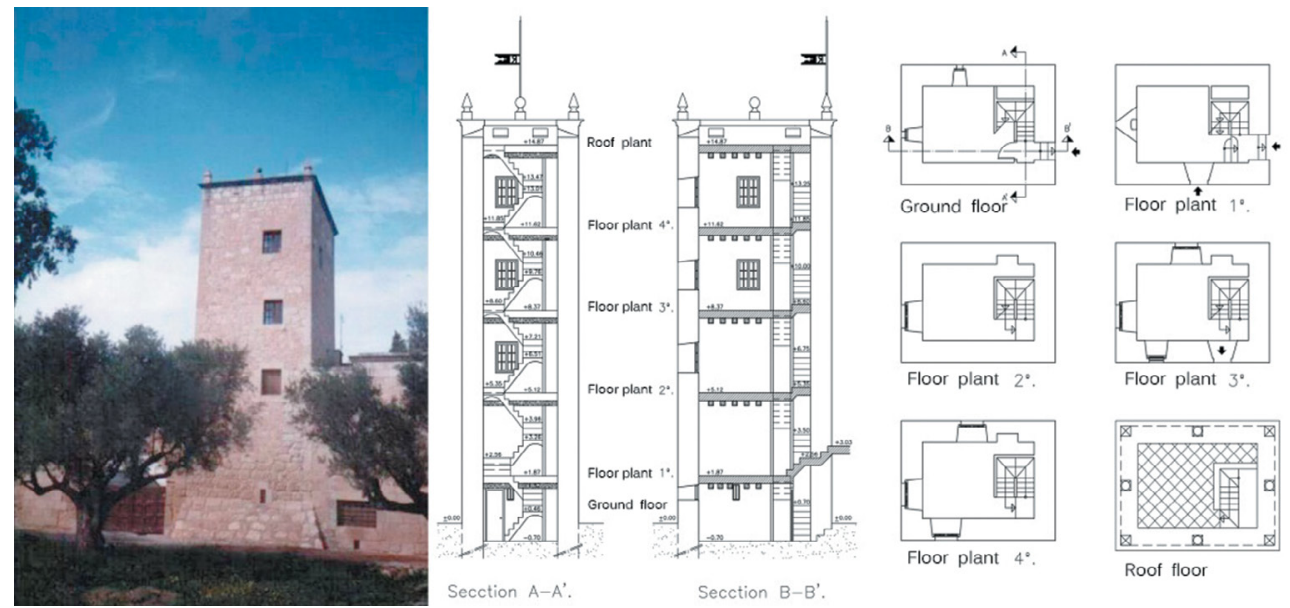

Figure 3: Rejas Tower-general view, sections and plants.

On the first floor appears the door that connects the house and the tower. Originally this was the only entry door to the tower. The door measures $1 \times 0.7$ metres. The door lintel has an arch shape by the side looking at the house but it is straight in the other side, overlooking the tower. The materials it is made of include thick wood crossbars and a heavy iron latch inserted in the wall (Fig. 4 (Left)). Then the staircase, which is very narrow, has a width of 70 centimetres, enlarging 10 centimetres in the compensated part. The stairway slab is built with a vaulted ceiling, with several sheets of bricks, mainly for the purpose of compression (Fig. 4 (Center and Right)).

In this floor there are two loophole windows; these elements will appear again in the last floor (Fig. 5 (Left)). On the second floor, there appears the first of the three windows placed
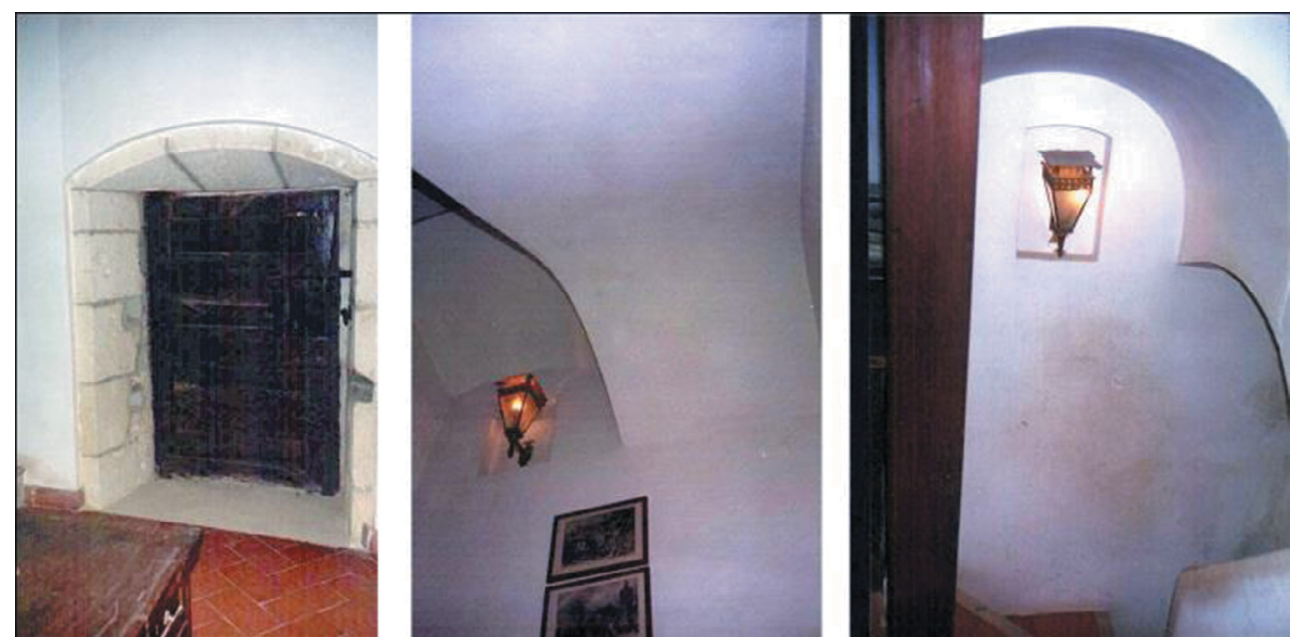

Figure 4: Left - communication door of the house and tower located on the first floor. Center and right - slab staircase. 


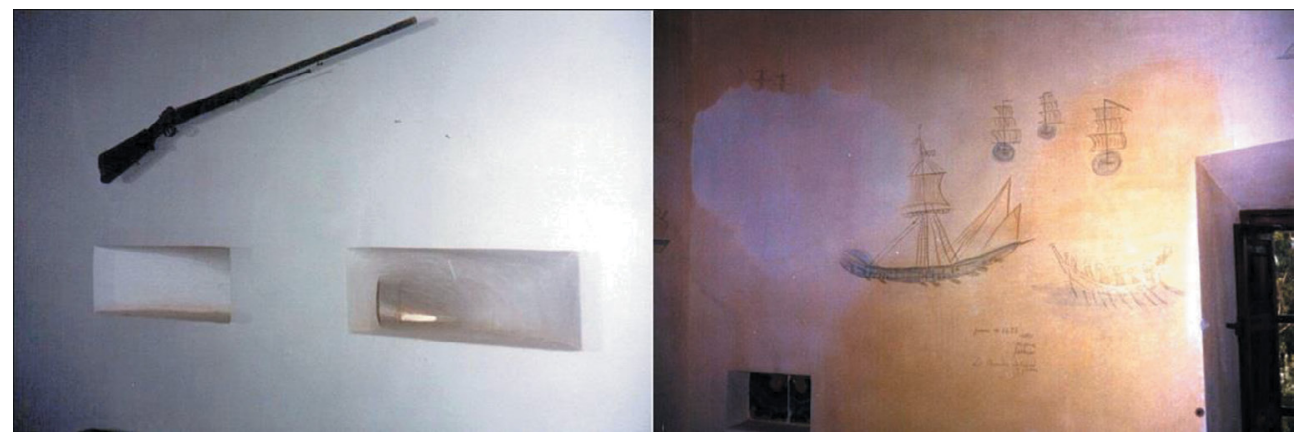

Figure 5: Left - the loopholes of the wall. Right - the paintings of the tower.
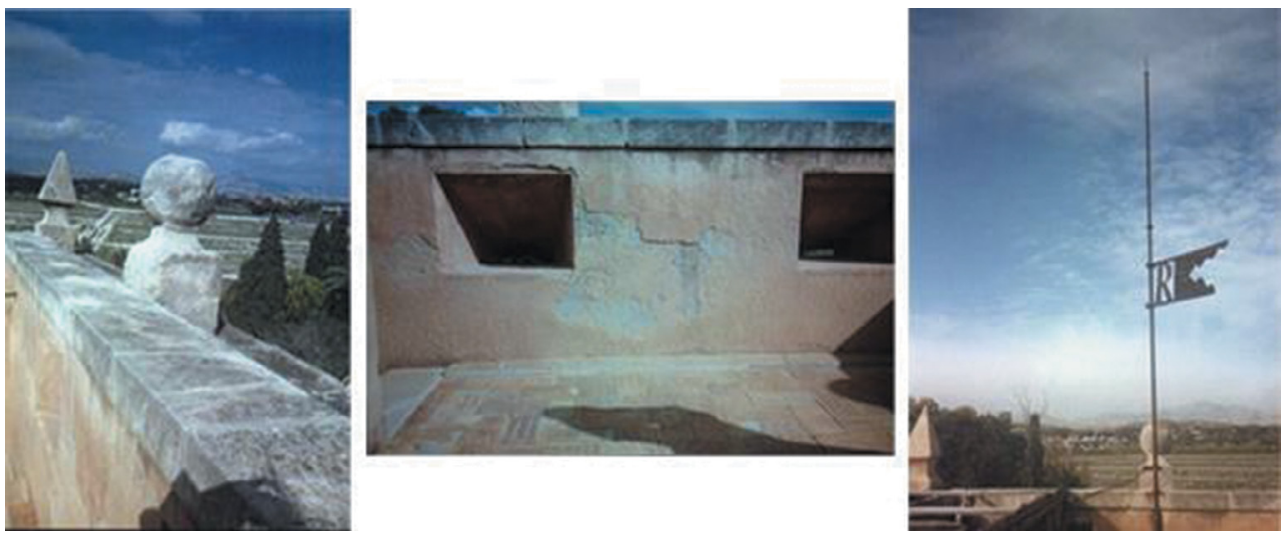

Figure 6: Left - the pinnacles of the tower. Center - the loopholes. Right - weathervane.

at the south-east facade. They measure $0.9 \times 1.20$ metres; they have no trellis and are framed by ashlars to the outside. The tower slabs have wooden beams arranged parallel to the smaller side of the tower, and they have square section. On the third floor of the tower are inscriptions and drawings of boats on all walls (Fig. 5 (Right)).

The roof parapet of the tower is one metre high, is plastered with lime mortar and has loopholes on three sides. The dimensions are $0.6 \times 0.35$ metres in the interior, decreasing in sections with inclined planes to the outside, until leaving a minimum opening (Fig. 6 (Center)). Eight pinnacles are arranged on the stone cornice. In the corners they are pyramid shaped and at the midpoints of the sides they are spherical in shape (Fig. 6 (Left)). At least, a weathervane appears with an 'R' design that refers to the name of the house (Fig. 6 (Right)).

\section{CONSTRUCTIVE FEATURES OF THE HOUSE}

The construction of the house is later than that of the tower. The main towers were built in the 16 th century meanwhile the houses were built in the 17 th and 18 th centuries. The house is a quadrangular building, in two heights, with agricultural dependencies which sometimes are exempt from the dwelling, but other times they form part of the houses, being able to detract from their typology of rectangular plant. The basic type is structured around two parallel porticos to the entrance facade. They are connected by a half-point arch. The entrance lobby has 
two heights of the house. The arch of this room is the most important characteristic element of the house. It has large dimensions, about 5 metres width. The roofs are sloped, with curved roof tiles. The aesthetic aspects are sober.

The exterior ornamentation of the facades is minimal; it is reduced to the perimeter of the hollows with ashlars, the mouldings of cornices and the mesh grids in the windows. Sometimes there is the coat of arms as a heraldic symbol. The main material is the stone, used in the walls and in the pavement halls. The wood is used for the joists with approximately 15 centimetres height and separates at about 35 centimetres. The beam filling is solved with ceramic brick stuffed with rubble and plastered with plaster [11, 12].

\subsection{Rejas House - Description}

\section{Ground floor}

The house has a quadrangular plant, with ground floor and first floor. The architectural planes before its reform of the 1950s allow us to compare what it was and what is. The yard (at the entrance on the right) is where the chapel rises today, and the winery (in the background) has been suppressed. However, the hall at two heights, the large arch of half a point and the staircase have not undergone changes. Another structural element that has disappeared is the spiral staircase of the tower (Fig. 7). The current distribution of the house has been adapted to the new uses so the distribution of the ground floor has changed. Since 2000, the house with tower 'Rejas' has been transformed into a restaurant.

The access door is on the North East facade and its dimensions are $3.4 \times 2.3$ metres. This door leads to the lobby. The hall has two heights, so its ceiling is directly formed by the intrados of the roof. At the interior, the hall has a sloping plane, with wooden beams arranged orthogonally to the access facade (Fig. 8). The hall appears to be the large half-point arch parallel to the entrance door. This arch has a width of 5.1 metres. At 3.2 metres from the ground is placed the arch's start, and the top is located at about 5.8 metres. It consists of about 30 stone pieces joined with lime mortar. The arch joins the pilasters of the start with imposts

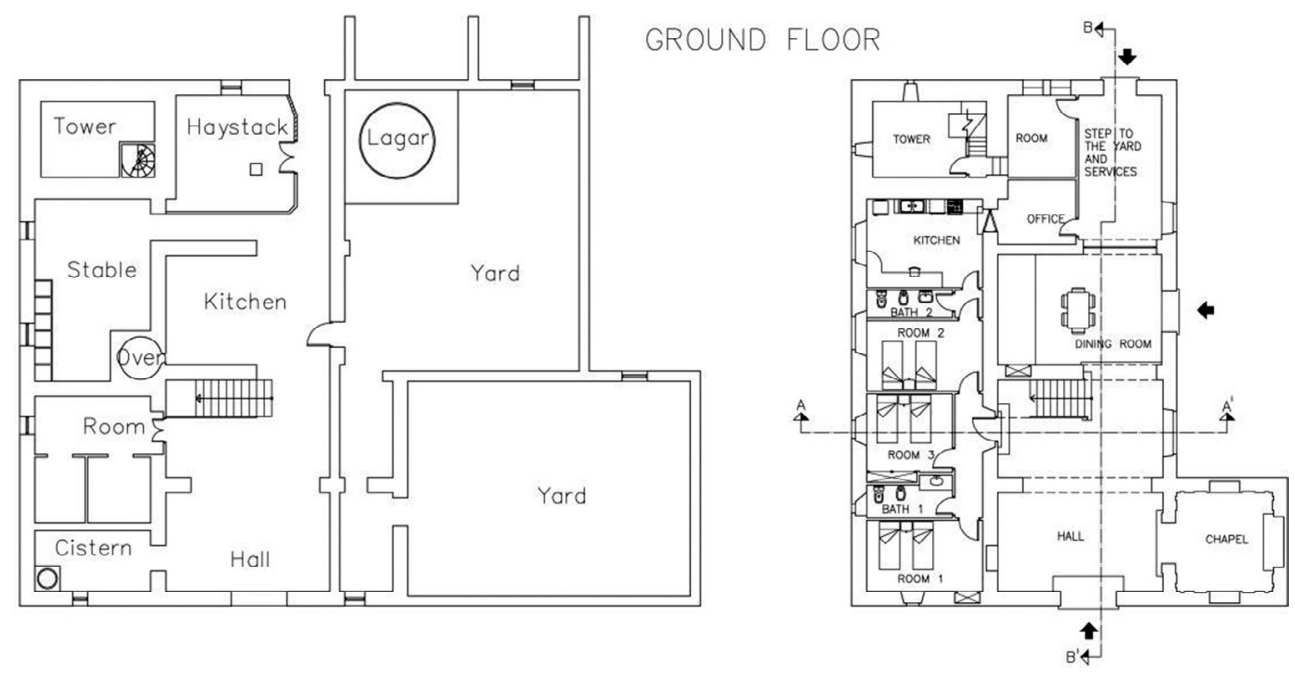

Figure 7: Left - original ground-floor plan. Right - ground floor after the 1950s reform carried out by the architect D. Miguel López González. 

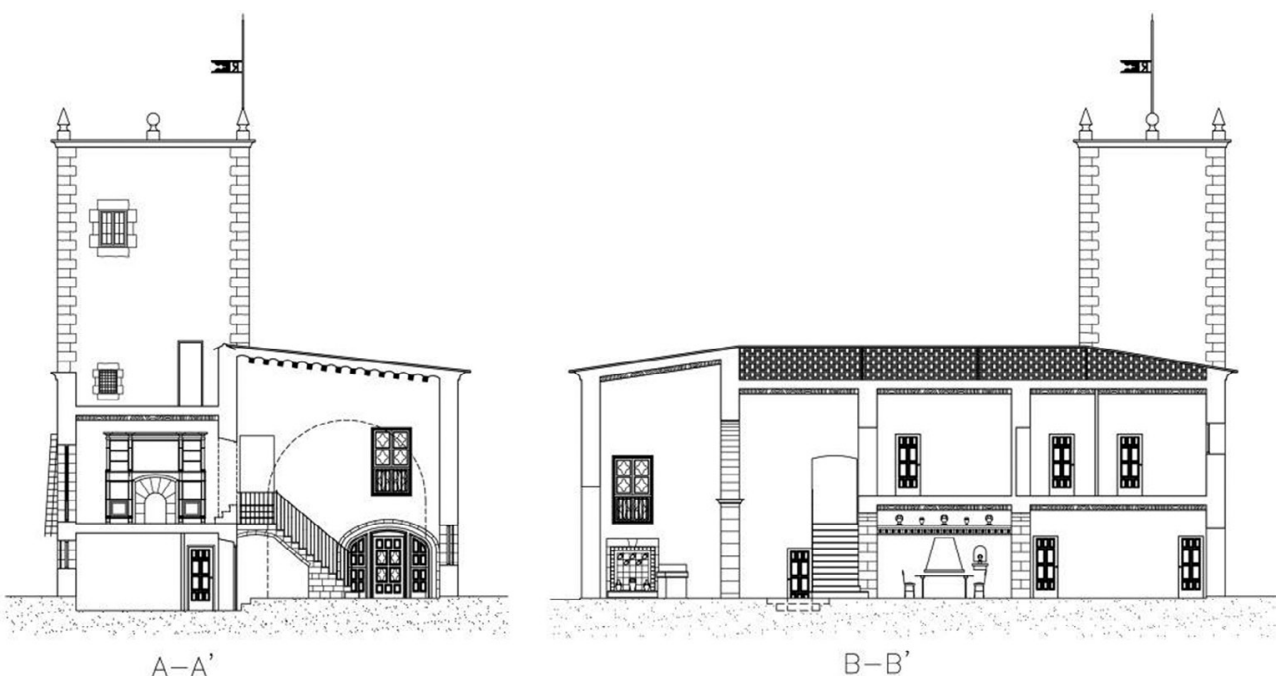

Figure 8: Left. A-A' cross section. We can see the entrance door to the tower at the first floor and the two levels hall with the big arch. Right. B-B' longitudinal section, a house global vision.

with mouldings (Fig. 9 (Left and Center)). In addition, next to the ladder there is another smaller arch (Fig. 9 (Right)).

The main house staircase is made of stone. It has a total of 12 steps, all of them with the same length, except the first one that is longer. The handrail is simple without decoration and is formed by square bars made of wrought iron (Fig. 10).

First floor

On the first floor stands the living room that connects the tower. It is a rectangular room with $10.2 \times 4.6$ metres. The wood beams are arranged parallel to the smaller side of the room.
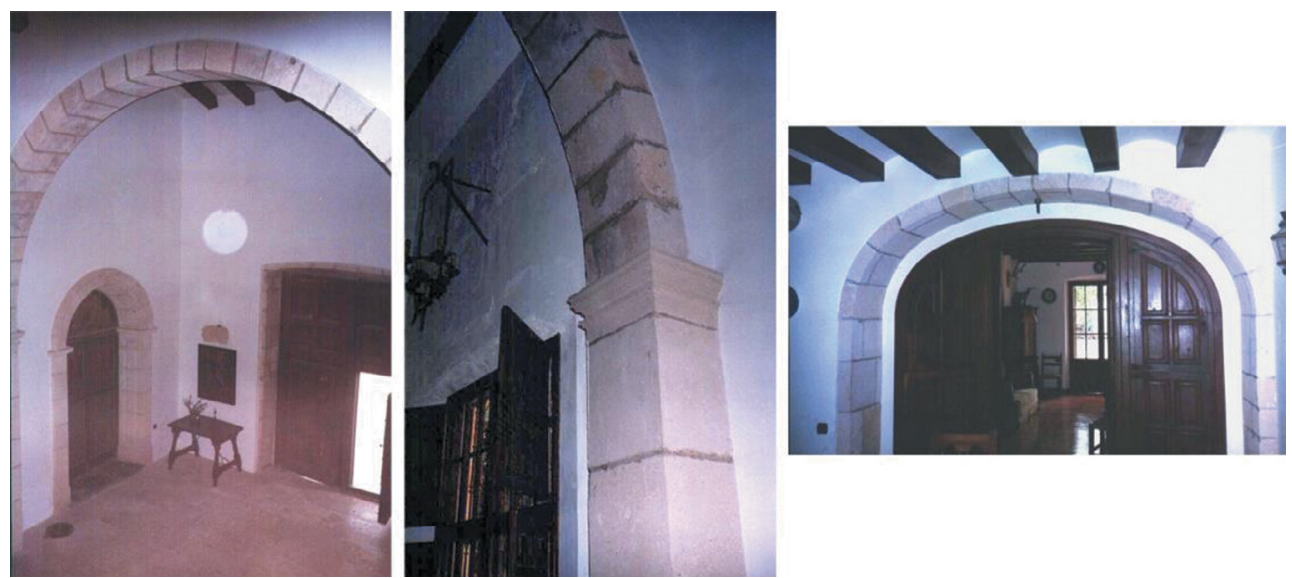

Figure 9: Left - interior view of the lobby. Center - the main arch of the hall. Right - arch of communication between lobby and dining room. 


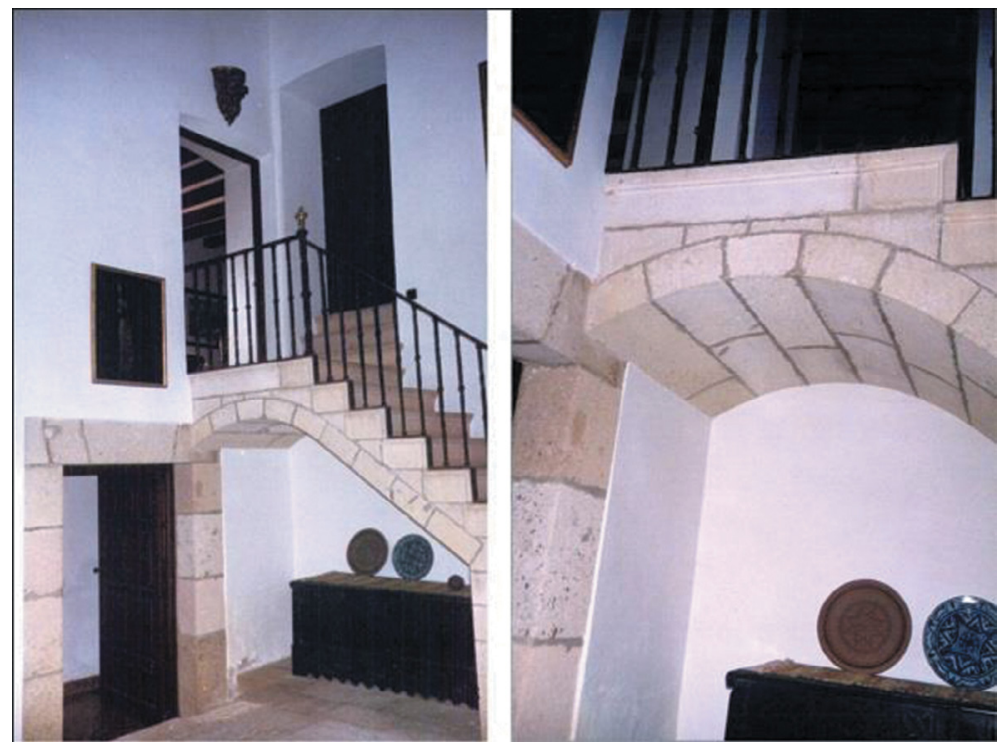

Figure 10: Staircase hall.

\section{First floor}

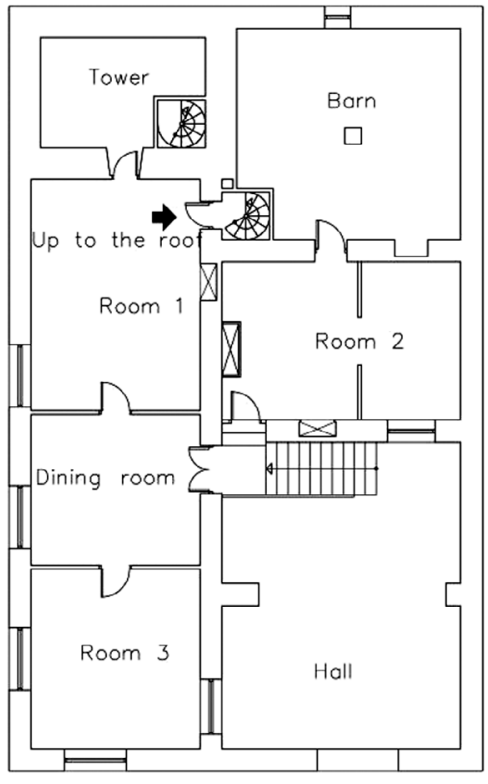

Original state

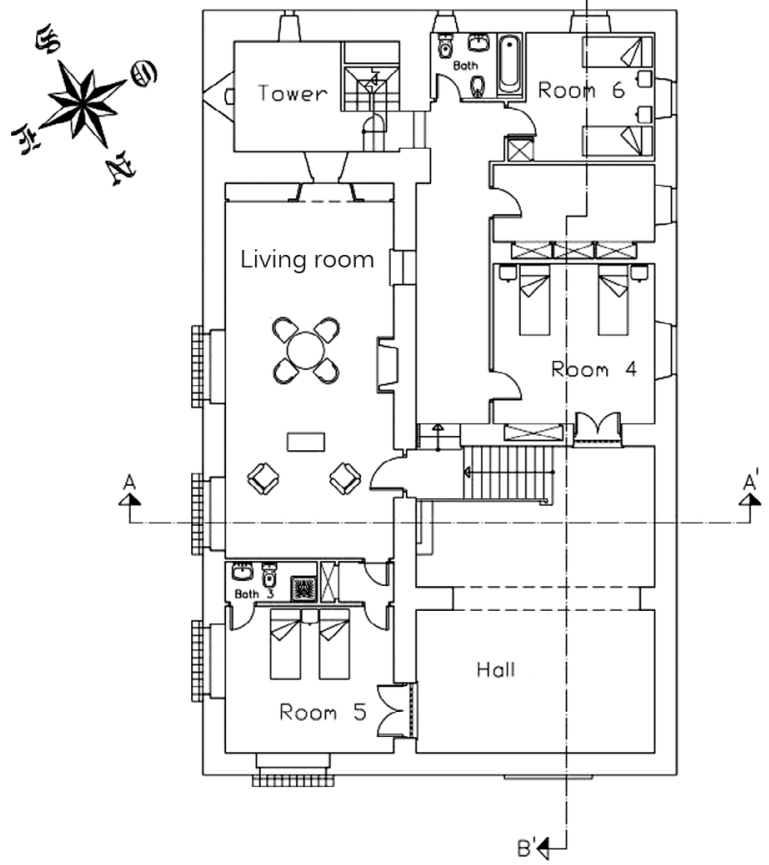

State after the 1950s reform

Figure 11: Left - original first-floor plan. Right - first floor after the 1950s reform carried out by the architect D. Miguel López González. 
They are similar to the lobby and the tower ones. At the entrance, to the right there is a stone fireplace. There is a library that covers the entire front of the wall. In the furniture symmetry axis, the door that connects the tower appears. The illumination comes from outside through two of the three large windows facing the south-east façade. This house's name "Rejas" in Spanish refers to the security elements outside the windows made with great magnitude iron bars (Fig. 11).

\section{CONCLUSIONS}

Rejas Tower is one of the most outstanding and best preserved towers in this territory. Nowadays the Rejas Tower persists with the original materials: stone and wood mainly. These materials are combined in the way to create own constructive systems which are typical from this kind of architecture placed in La Condomina area. The main characteristic inside the house is the hall in two heights divided by a large central arch. Its architectural interest as well as the construction techniques and original materials used are the aspects that make this building as an important exponent in the defensive architecture in Alicante during this period.

\section{REFERENCES}

[1] Pastor de la Roca, J., Historia General de la Ciudad y Castillo de Alicante, Editorial Maxtor Edición facsim il, Alicante, 1854.

[2] Seijó Alonso, F., Arquitectura alicantina, El Riu- Rau, la Masía, la Alquería, etc, Ediciones Alicante: Alicante, 1975.

[3] González Cascales, F., Torres de Vigía en La Marina Alta, Tribuna de la Construcción, Septiembre 1992, Año I No5.

[4] Seijó Alonso, F., Los Piratas en La Condomina, Ediciones Diario Información, Alicante 23-11-64.

[5] Mateo Box, J., Castillos de la provincia de Alicante, Ediciones Banco de Alicante, Alicante, 1987.

[6] Seijó Alonso, F., Torres de La Condomina, Diario Información, Alicante 15-11-64.

[7] Seijó Alonso, F., La Vivienda Popular Rural Alicantina. Tomos Iy II, Ediciones Alicante: Alicante, 1979.

[8] VVAA, Quinto Centenario de la Ciudad de Alicante, Ediciones Diario Información - Ayuntamiento de Alicante, Alicante 1989.

[9] Varela Botella, S., Catálogo de Edificios y Elementos en La Huerta de Alicante, Ediciones Ayuntamiento de Alicante, Alicante 1983.

[10] De Mora Figueroa, L., Glosario de Arquitectura Defensiva Medieval, Ediciones Servicio de Publicaciones de la Universidad de Cádiz. Cádiz, 1994.

[11] Calduch Cervera, J. \& Varela Botella, S., Guía de Arquitectura de Alicante, Ediciones Colegio de Arquitectos de Alicante. Alicante, 1979-1980.

[12] Del Rey Aynat, J., Arquitectura Rural Valenciana. Tipos de Casas y Análisis de su arquitectura, Ediciones Generalitat Valenciana, Valencia, 1998. 